\title{
【雑感】国際社会における温暖化問題の現実 とエネルギー政策の議論
}

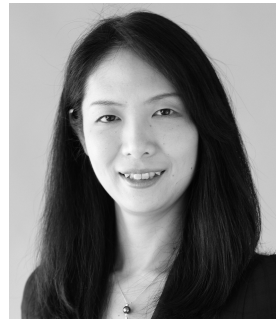

藤沢 久美 $($ ふじさわ・くみ $)$

シンクタンク・ソフィアバンク代表 大阪市立大学卒業後, 国内外の投資運用 会社に勤務。日本初の投資信託評価会社, アイフィスを起業。「社会起業家フォーラ ム」副代表などを経て現職。

著書は「なぜ，御用聞きビジネスが伸びて いるのか」(ダイヤモンド社)など。

\section{排出権取引への疑問}

私が温暖化問題やエネルギーについて興味を持つよう になったのは，「排出権取引」が話題になったときだ。当 時の私は, 京都議定書は世界の温暖化問題を解決する地 球の未来にとって重要な合意であると漠然と考えていた ほど，温暖化問題にも，エネルギー政策にも，そして国 際社会についても知見はなかった。ただ，長らく関わっ てきた投資信託の業界において，モーゲージ(住宅ロー ンなどの不動産担保融資の債権を担保として発行される 証券)などを用いたファンドの組成に関わっていたこと もあり，「排出権取引導入を大手新聞社が諸手を上げて 歓迎していることに，いささか疑問を感じたのである。

モーゲージは結局，サブプライムローン問題を引き起 こすことになったが，それでも担保には不動産という目 に見えるものがあり，そもそも不動産の価格決定も実物 を元にした需給で決まるが, 排出権取引の担保に当たる 温室効果ガスは，そもそも実物でもないし，需給のバラ ンスを管理する市場も世界標準があるとは言いがたい状 況であり，こうした場合は，ほほ確実に，市場のルール を創り，市場運営者が儲けることになる。金融に限らな くても，ルール設定した者が，最も利益を得ることは， 世界標準を持つ様々な分野で既に明らかになっている。

\section{COP で感じた温暖化問題の終わりの始まり}

こうして排出権取引に対する疑念が，様々な関係者と の出会いへとつながり，全く門外漢である私が，温暖化 問題やエネルギー政策などについて，学ぶ機会を持つこ ととなった。中でも，21世紀政策研究所澤昭裕研究主幹 からご指導をいただき，COP15への参加の機会を与え ていただいたことは，温暖化問題と国際社会の駆け引き を体験を持って学ぶ機会となり, 涾く感謝している。コ ペンハーゲンで開催された COP15から南アフリカの ダーバンで開催された COP17まで， 3 年に渡って COP に参加し，3つのことを実感した。一つは，世界の意思 決定の仕組みの変化, 二つは, 温暖化問題の終わりの始 まり，三つは，外交交渉の場としての駆け引きである。
まず，世界の意思決定の仕組みの変化だが，新興国や 途上国の台頭により，かつての先進国が呈示したルール に追随する国はもはや抢らず，先進国と新興国の互いの 利害の違いと, 経済成長力・資源力などを持つ新興国の 存在感のアップによって, 先進国が中心になって世界の ルールを決める時代は終わってしまった。京都議定書的 な世界統一ルールは，もはや成立しない現実を, 誰もが 痛感した。そして, COP は, 世界の多様な取組みや条 件を互いに認め合うというよりも，とりあえずテーブル に載せて品評する場になりつつあるように感じた。

そして，二つ目の温暖化問題の終わりの始まりにつな がるのだが, COP 会場には, 多くの NGO が参加してい る。胸に「I LOVE KP(京都議定書)」と書かれた T シャ ツを着た人も見かける。こうした $\mathrm{NGO} の$ 方々に，スポ ンサーは誰かと尋ねると，多くの場合が欧州の金融機関 であり，結局のところ，排出権取引によって利益を得る 金融機関がNGO を経済的に支援し, 彼らに京都議定書 を守る運動を通じて，排出権市場の確立の後押しをして もらうという構図ができている。さらに，こうした NGO の人々に,「日本は京都議定書に反対を貫いているのだ けど，どう思う？」と問いかけてみたところ，「そうみた いだね。どうしてだろうね。」といった，軽い反応が返っ てくることもしばしばで，まるで年に 1 回の㧍祭りを楽 しみに来ているような人もいた。COP1の頃とは参加 者の意識も大きく変わり, 惰性となっている参加者も多 いのではないかという印象を受けた。

そして, 三つ目の外交交渉の場としての色合いが, 恐 らくCOP 1 の頃よりさらに色濃くなっているのではな いかと思う。先進国が互いにメリットを分け合いながら 温暖化に対するルールづくりを始めた当初とは異なり， 誰がもっともルールを通じてメリットを得るかの戦いの 場になってしまったようだ。先に述べた通り，その背景 には，新興国の台頭もあり，私が目にした COP の現場 では，いかにしてルール設定のイニシアティブをとり， 自国への経済的メリット等を最大化するかに各国がしの ぎを削っていた。 
その中で, 異色を放っていたのは, 日本政府の交涉だっ た。各国が自国の権利の主張をするなか, 日本も京都議 定書からの離脱を宣言したが, 単なる離脱ではなく, 日 本政府は世界の温暖化問題の解決に向けての現実的なア プローチを提案し続けてきた。しかし，こうした日本政 府のスタンスは, 残念ながら日本のメディアでは報道さ れず，京都議定書離脱宣言が各国から批判されたという ようなネガティブな報道のみで, 日本のメディアは自国 の応援をするのではなく, まるで他国の応援団のごとく 報道をするという現実にも呆然とした。

日本のエネルギー政策や産業政策に大きく関わる温暖 化問題を取り巻く環境は, 前述の通り変化しているにも 関わらず，日本国内では，表面的な議論が多いように感 じるのは，私だけだろうか。この私の懸念は，東日本大 震災以降のエネルギーに対する議論にも通じるところが ある。

\section{世界経済フォーラムに見る日本のエネルギー政策}

私は, 温暖化問題への関わりを通じて, 日本のエネル ギー政策についても学ぶ機会を得た。なぜ日本がエネル ギーミックスにいち早く取り組んだのか, そこに原子力 を取り入れたのか, なぜ温暖化の原因となる石炭火力を 廃止しないのか, エネルギーの専門家ならば当然持って いる知識を私は持ち合わせていなかった。日々消費して いる電気が，どのような政策によって水や空気のような 当たり前の存在へと進化してきたかを知ることとなっ た。そして，もっと国民全体が，この歴史を知り，これ からのエネルギーについて考え, 議論する機会が必要で あると思った。そうした矢先に, 東日本大震災が起き, 福島第一原発の大事故が発生し, もはや, エネルギーに ついて, 冷静に議論することはできなくなってしまっ た。

こうした日本のエネルギー政策について, 海外は冷静 に議論をしている。私は，2007年からダボス会議を主催 する世界経済フォーラムのヤング・グローバル・リー ダーとして, フォーラムの様々な議論に参加する機会を 与えられている。世界のトップ企業やトップアカデミア たちが集まるその場では, 様々な分野にいての議論が行 なわれ，エネルギーについても New Energy Architec- ture という審議会にて，世界の有識者と関係者がメン バーとなり議論が行なわれている。東日本大震災が発災 した2011年に，この審議会は，日本とインドをターゲッ トカントリーとして，提言を発表している。

その一部を以下に，紹介する。

「日本は長期的に見て,エネルギー構成のイノベーショ ンや他国のお手本となるような新たなエネルギーモデル の構築をけん引する存在となる可能性があり, そのため には，次の 4 つの目標を掲げるべきである。1. 日本経済 をけん引する輸出産業を育てるための再生可能エネル ギーの拡大と新エネルギー産業のサポート。2. 原子力発 電は，日本のエネルギーミックスにおいて引き続き重要 な役割を担う存在であるが故のより強い原子力産業とな るような研究開発の継続，パブリックアクセプタンスを 獲得するための説明責任と透明性の確立。3. 再生可能工 ネルギーの可能性の拡大および経済的・技術的効率性を 拡大するような電力の送配電のための新たな市場とイン フラの開発。4.エネルギー効率において新しいベストプ ラクティスモデルの創出。」

この提言からもわかるように，世界経済フォーラムで のエネルギーに関する議論は冷静である。もちろん，原 発事故は, 深刻に受け止められ, 議論の対象となったが, 新興国の成長を支えるエネルギー源としてどのように活 用し，安全を担保していくかの議論が積極的に行なわれ ていた。原子力の危険性については，主にテロという側 面からの議論のみで，発電所としての危険性はほぼ議論 の対象外となっていた。エネルギーの素人である私から 見ると, 世界での議論は, 超長期的には再生可能エネル ギーなど新たな代替エネルギーへの挑戦を積極的に行な いつつ，その実現までの実用的エネルギー源として原発 を位置づけているような印象を受けた。日本で議論され ている廃炉や使用済み燃料についての議論はあまり目に しなかった。その意味でも,核廃裹物の処理に関しては, 日本は世界のリーダーとなる可能性はあるのではないだ ろうか。

こうした世界での議論ももっと日本国内に幅広く フィードバックし, エネルギーの未来について, 冷静に 議論できることを願う。

（2013年 6 月19日 記） 